\title{
Prognostic Significance of NSCLC and Response to EGFR-TKIs of EGFR-Mutated NSCLC Based on PD-L1 Expression
}

\author{
KENICHI KOBAYASHI ${ }^{1}$, MASAHIRO SEIKE ${ }^{1}$, FENFEI ZOU ${ }^{1}$, RINTARO NORO ${ }^{1}$, MIKA CHIBA ${ }^{1}$, \\ ARIMI ISHIKAWA ${ }^{2}$, SHINOBU KUNUGI ${ }^{2}$, KAORU KUBOTA $^{1}$ and AKIHIKO GEMMA ${ }^{1}$ \\ ${ }^{I}$ Department of Pulmonary Medicine and Oncology, Graduate School of Medicine, \\ Nippon Medical School, Tokyo, Japan, \\ ${ }^{2}$ Department of Analytic Human Pathology, Graduate School of Medicine, Nippon Medical School, Tokyo, Japan
}

\begin{abstract}
Background/Aim: Recent clinical trials have shown that immune checkpoint blockades that target either $P D-1$ or PD-L1 yield remarkable responses in a subgroup of patients with non-small cell lung cancer (NSCLC). Materials and Methods: We retrospectively examined, by immunohistochemical analysis, 211 NSCLC samples. Using 32 independent samples, we also evaluated PD-L1 expression in NSCLC patients with EGFR gene mutations treated by EGFR-TKIs. Results: Overall survival of PD-L1positive stages I-III NSCLC and stage I NSCLC and stages I-III squamous cell carcinoma (SQ) were significantly shorter than those of PD-L1-negative NSCLC $(p<0.01$ and $p=0.02$ and $p=0.01$, respectively). In stage I NSCLC and stages I-III SQ, PD-L1 expression was found to be independent predictor of death after multivariate analysis. Response to EGFR-TKIs was not significantly different between PD-L1-positive and PD-L1-negative NSCLC patients with EGFR mutations. Conclusion: PD-L1 expression was a significant independent predictor of poor outcome in NSCLC patients.
\end{abstract}

Lung cancer is the leading cause of cancer-related deaths worldwide (1). The development of molecular-targeted therapy has improved the survival of non-small cell lung cancer (NSCLC) patients over the past few years (2-4). Recently, immune checkpoint mechanisms in the functional reaction between tumor and immune cells were revealed as novel therapeutic targets in human cancer, including NSCLC.

Correspondence to: Dr. Masahiro Seike, Department of Pulmonary Medicine and Oncology, Graduate School of Medicine, Nippon Medical School, Tokyo 113-8603, Japan. Tel: +81 338222131, e-mail: mseike@nms.ac.jp

Key Words: PD-L1, lung cancer, EGFR-TKI, prognosis, EGFR mutation.
The human anti-PD-1 antibodies, nivolumab and pembrolizumab, have shown significant survival benefits over docetaxel in phase 3 trials of refractory NSCLC patients (5-7). Based on these trials, the Food and Drug Administration (FDA) has approved both nivolumab and pembrolizumab as single agents for second-line therapy of patients with advanced NSCLC (6, 7). Anti-PD-L1 antibodies such as atezolizumab and durvalumab are presently in clinical development $(8,9)$. Atezolizumab significantly improved survival compared with docetaxel in patients with previously treated NSCLC and has been approved as a drug for second-line therapy (8).

PD-L1 is an immune checkpoint protein expressed on tumor cells and tumor-infiltrating immune cells. PD-L1 suppresses anticancer immunity by binding to its receptors, PD-1 and B7-1. PD-L1 expression can be used as a predictive biomarker for PD-1 and PD-L1 antibody therapy (5-7, 10). Patients treated with nivolumab did not show superior progression-free survival (PFS) compared to platinum-based chemotherapy as first-line therapy in advanced NSCLC patients with $5 \%$ or more PD-L1 tumor expression (11). In contrast, pembrolizumab is currently approved for NSCLC patients with over 50\% PD-L1 overexpression in the first-line cohort (10). Pembrolizumab was approved by the FDA for the first-line treatment of advanced NSCLC patients whose tumors expressed PD-L1 as determined by an FDA-approved companion test. Several studies have also demonstrated a correlation between PD-L1 expression on NSCLC cells and the clinicopathological characteristics of patients with NSCLC (12-18).

About $20-30 \%$ of early-stage NSCLC patients undergo relapse after complete surgical treatment (19). Adjuvant chemotherapy based cisplatin for resected stages IB, II and IIIA NSCLC have improved survival for patients with earlystage, however, the prognosis of NSCLC after recurrence remains poor (20-22). Pre- and post-adjuvant chemotherapy using immune checkpoint inhibitors is a promising 
therapeutic strategy. However, the correlation between PDL1 protein expression and patient survival is still unclear.

PD-L1 was strongly associated with the presence of EGFR mutations, potentially modulating patients' sensitivity to antiEGFR agents $(15,16,23)$. However, in three phase III studies of immune checkpoint inhibitors that include nivolumab, pembrolizumab, and atezolizumab compared with docetaxel during second-line theraphy, immunecheckpoint inhibitors did not significantly prolong overall survival (OS) compared with docetaxel in the EGFR-mutant subgroup (Harzard Ratio $[\mathrm{HR}])=1.18,95 \%$ Confidence interval $[\mathrm{CI}]=0.69-2.00$; $\mathrm{HR}=0.88,95 \% \mathrm{CI}=0.45-1.70 ; \mathrm{HR}=1.24,95 \% \mathrm{CI}=0.71-2.18$, respectively) (6-8). Meta-analysis also showed that immune checkpoint inhibitors did not improve OS over docetaxel during second-line therapy in EGFR-mutant NSCLC patients (24).

The significance of PD-L1 protein expression in prognosis is also unclear in EGFR-mutant NSCLC patients. In this study, we evaluated the prognostic significance of PD-L1 protein expression in NSCLC patients by immunohistochemical analysis (IHC). We also examined the correlation between the expression of PD-L1 and the response to EGFR-tyrosine kinase inhibitors (EGFR-TKI) in NSCLC patients with an EGFR mutation.

\section{Materials and Methods}

Patients and tumor samples. We carried out a retrospective study of 211 NSCLC patients who had undergone complete surgical resection between 2001 and 2009 at Nippon Medical School Hospital. None of the patients had received therapy using immune checkpoint inhibitors. We also analyzed 32 NSCLC patients with an EGFR gene mutation treated by first generation EGFR-TKIs as first-line therapy between 2004 and 2010 as an independent set. The thirty NSCLC patients received gefitinib and two patients received erlotinib therapy, respectively. Tumor samples from 32 EGFRmutant NSCLC patients were obtained by surgical resections and transbronchial lung biopsies before EGFR-TKIs treatments. With regard to $E G F R$ mutation status, 20 patients harbored a deletion in exon 19 and 12 patients had an L858R missense mutation in exon 21. None of the other mutations including exon 20 insertions, were found. In patients who underwent surgery, overall survival was measured from the date of lung cancer surgery until the date of death, and disease-free survival (DFS was measured from the date of surgery until relapse. In the EGFR-mutant NSCLC patients, overall survival was measured from the date when EGFR-TKI treatment was started until the date of death, and PFS was measured from the date when treatment was started until progression. TNM staging, including $\mathrm{T}$ factor, $\mathrm{N}$ factor and tumor differentiation grade (G), was assessed by the latest TNM staging system and by following the 7 th edition of the American Joint Committee on Cancer Staging Manual (25-27). Specimens from all NSCLC patients were used only for IHC analysis. The study protocol was approved by an ethics committee review board at Nippon Medical School Hospital. Written informed consent was obtained from all patients and patient samples were examined according to the Declaration of Helsinki, 2008.
Detection of EGFR mutations. The peptide nucleic acid-locked nucleic acid polymerase chain reaction (PNA-LNA PCR) clamp method was used to identify EGFR gene mutations in tissue or cytology specimens by LSI Medience Corporation (Tokyo, Japan), as previously described.

Immunohistochemistry. IHC was consecutively performed on formalin-fixed, paraffin-embedded sections. After deparaffinization, sections were quenched for endogenous peroxidase activity with $0.3 \%$ hydrogen peroxide plus absolute methanol for $30 \mathrm{~min}$. Thereafter, antigen retrieval was carried out in a $10 \mathrm{mmol} / \mathrm{L}$ citrate buffer solution (LSI Medience Corporation) for 15 min using an autoclave. After blocking with $2 \%$ normal swine serum (Vector Laboratories Inc., Burlingame, CA, USA), sections were washed and incubated with rabbit anti-CD274/B7-H1/PD-L1 polyclonal antibody (1:400 dilution; LifeSpan BioScience, Inc, Seattle, WA, USA) overnight at $4^{\circ} \mathrm{C}$. After washing, slides were incubated for 30 min with anti-rabbit antibody against vimentin (1:200 dilution; Vector Laboratories, Burlingame, CA, USA), and treated with an avidin-biotin complex kit (Funakoshi Co., Ltd., Tokyo, Japan). Finally, slides were exposed to 3, 3'-diaminobenzidine tetrahydrochloride (Muto Pure Chemicals Co., Ltd., Tokyo, Japan), followed by counterstaining with Mayer's hematoxylin.

Immunohistochemical evaluation of PD-L1 expression. The percentages of PD-L1 positive tumor cells and staining intensity were evaluated for each sample. The intensity of cytoplasmic staining was scored 0 as negative or a trace, 1 as weak, 2 as moderate and 3 as high. Positive staining was defined as staining intensity 3 in more than $5 \%$ of tumor cells by a standardized scoring system according to a previous study (15).

We also evaluated membrane staining for each sample. All slides were reviewed and scored independently by two investigators (KKo and $\mathrm{RN}$ ) who were blinded to clinical information pertaining to patients.

Statistical analysis. Correlations between IHC staining and clinicopathologic factors were determined using the chi-square test or Fisher's exact test. Kaplan-Meier survival curves were drawn for overall survival and DFS, and compared by log-rank test. Univariate and multivariate analyses were performed using the Cox proportional hazard model. All tests were two-sided, and a $p$-value of less than 0.05 was considered statistically significant. Statistical analyses were performed using IBM SPSS Statistics version 21 (IBM SPSS, Inc., Armonk, NY, USA).

\section{Results}

PD-L1 expression in surgical NSCLC patients. Of tumor specimens for IHC analysis from 211 patients who had undergone surgery, cytoplasmic staining for PD-L1 revealed that $104(49 \%)$ specimens were positive (PD-L1+), and 107 (51\%) were negative (PD-L1-; Figure 1; Table I). Membrane PD-L1 staining showed that 121 (57\%) specimens were PDL1-positive, and 90 (43\%) were PD-L1-negative. A significant correlation between cytoplasmic and membrane staining was observed (Fisher's exact test: $p<0.01$ ). Associations between patient clinicopathologic parameters and PD-L1 status are shown in Table I. There were no 


\section{PD-L1-}
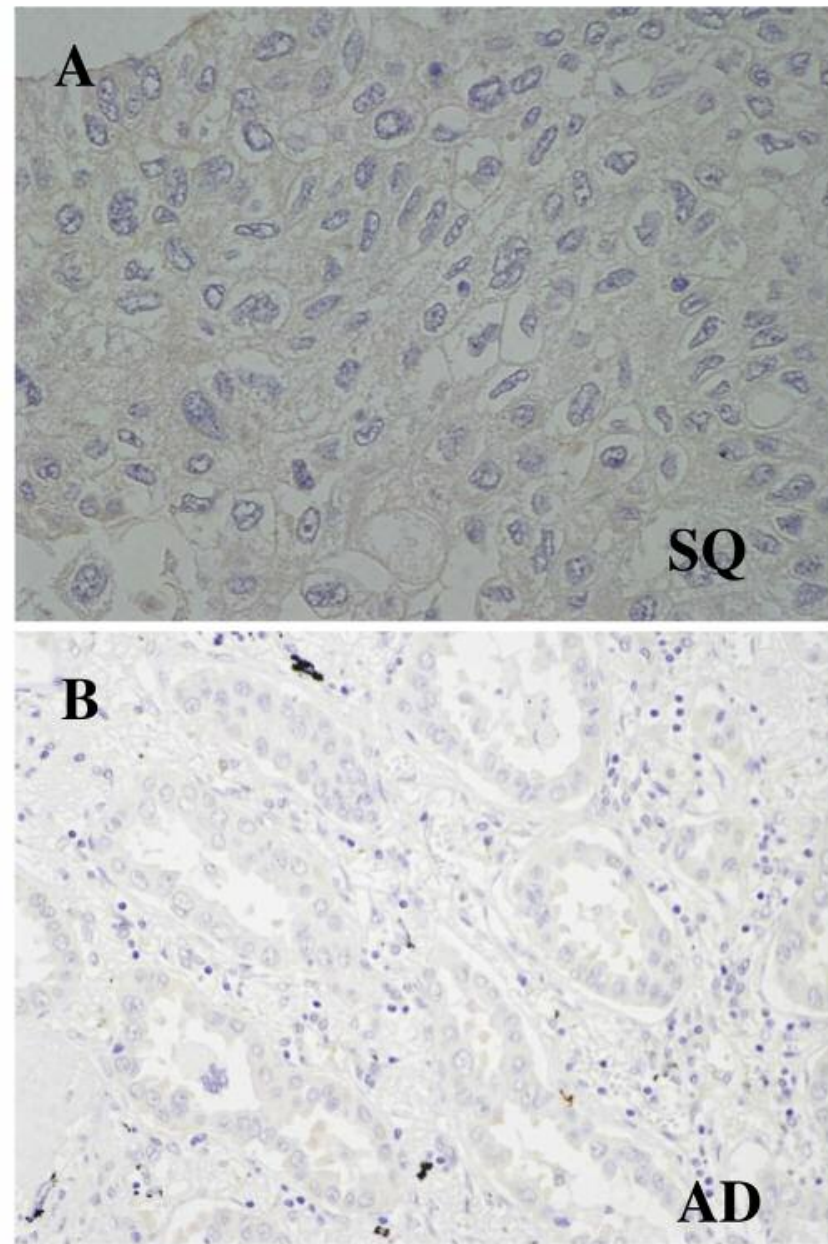

PD-L1+
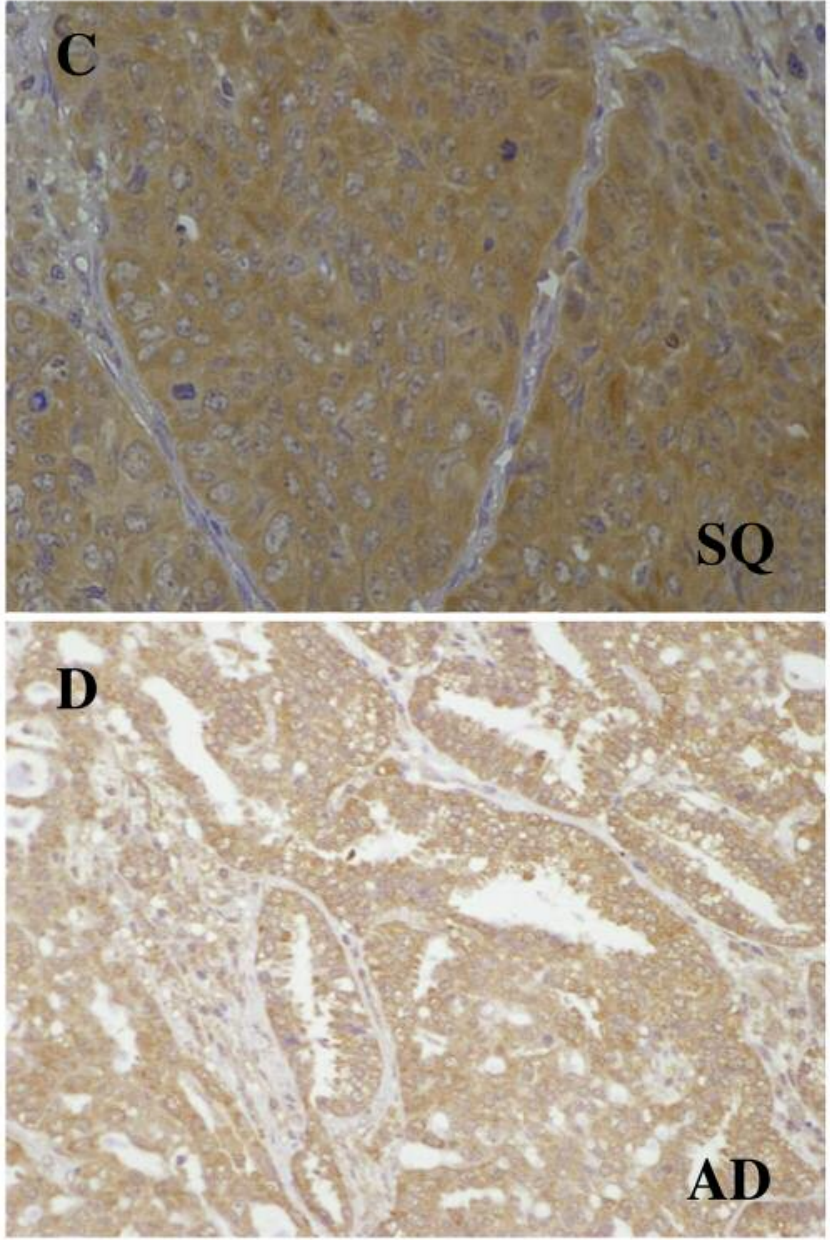

Figure 1. Immunohistochemical staining for PD-L1. Negative $(A, B)$ and positive $(C, D)$ staining patterns for PD-L1 are shown as determined by immunohistochemistry (IHC). $S Q$ : Squamous cell carcinoma; $A D$ : adenocarcinoma.

significant associations between PD-L1+ with parameters such as age, gender, smoking, $\mathrm{T}$ factor, $\mathrm{N}$ factor, clinical stage, tumor grade, and EGFR status. However, PD-L1 expression was significantly higher in adenocarcinoma than in squamous cell carcinoma (SQ; $p=0.014)$.

Association between PD-L1 expression and clinical outcome. We next evaluated the correlation between PD-L1 expression and patient prognosis. Overall survival of PD-L1 positive NSCLC patients with stages I-III disease was significantly shorter than that of PD-L1 negative NSCLC patients $(p<0.01$; Figure 2A). In 86 SQ cases, PD-L1 positive patients also showed significantly poorer overall survival than PD-L1 negative patients ( $p=0.01$; Figure $2 \mathrm{~B}$ ). In contrast, overall survival was not significantly different between PD-L1 positive and negative adenocarcinoma patients $(p=0.46$; $\mathrm{n}=125$; Figure 2C). Next, we investigated whether the prognosis was affected by PD-L1 expression among patients stratified according to stage. In stage I patients, overall survival and DFS rates for PD-L1 positive cases were significantly shorter than those for PD-L1 negative cases $(p=0.02$ and $p=0.03$, respectively; Figure $2 \mathrm{D})$.

The impact of PD-L1 expression on NSCLC patient survival. We next evaluated whether the prognostic ability of PD-L1 was affected by underlying clinicopathologic covariates using univariate and multivariate Cox regression analyses. Among stages I-III NSCLC patients, age (hazard ratio $[\mathrm{HR}] 1.85, p=0.02)$, gender (HR 2.49, $p<0.01)$, pathology (HR 1.83, $p<0.01)$, p-stage (HR 2.55, $p<0.01$ ), 
Table I. Association between PD-L1 expression and NSCLC patient characteristics.

\begin{tabular}{|c|c|c|c|c|}
\hline Variables & $\mathrm{N}$ & PD-L1+ & PD-L1- & $p$-Value \\
\hline \multicolumn{5}{|l|}{ Total, $n=211$} \\
\hline \multicolumn{5}{|l|}{ Age (years) } \\
\hline$<65$ & $61(29 \%)$ & $37(61 \%)$ & $24(39 \%)$ & \\
\hline $65 \leq$ & $150(71 \%)$ & $67(45 \%)$ & $83(55 \%)$ & 0.48 \\
\hline \multicolumn{5}{|l|}{ Gender } \\
\hline Male & $140(66 \%)$ & $65(46 \%)$ & $75(54 \%)$ & \\
\hline Female & $71(34 \%)$ & $39(55 \%)$ & $32(45 \%)$ & 0.25 \\
\hline \multicolumn{5}{|l|}{ Smoking } \\
\hline Never smoked & $51(24 \%)$ & $30(59 \%)$ & $21(41 \%)$ & \\
\hline Current/former smoker & $160(76 \%)$ & $74(46 \%)$ & $86(54 \%)$ & 0.15 \\
\hline \multicolumn{5}{|l|}{ Pathology } \\
\hline Squamous cell carcinoma & $86(41 \%)$ & $33(38 \%)$ & $53(62 \%)$ & \\
\hline Adenocarcinoma & $125(59 \%)$ & $71(57 \%)$ & $54(43 \%)$ & 0.01 \\
\hline \multicolumn{5}{|l|}{ Grade } \\
\hline G1 & $42(20 \%)$ & $21(50 \%)$ & $21(50 \%)$ & \\
\hline $\mathrm{G} 2-3$ & $169(80 \%)$ & $83(49 \%)$ & $86(51 \%)$ & 1.00 \\
\hline \multicolumn{5}{|l|}{$\mathrm{T}$ factor } \\
\hline $\mathrm{T} 1$ & $60(28 \%)$ & $28(47 \%)$ & $32(53 \%)$ & \\
\hline $\mathrm{T} 2-4$ & $151(72 \%)$ & $76(50 \%)$ & $75(50 \%)$ & 0.65 \\
\hline \multicolumn{5}{|l|}{$\mathrm{N}$ factor } \\
\hline No & $143(68 \%)$ & $75(52 \%)$ & $68(48 \%)$ & \\
\hline N1-2 & $68(32 \%)$ & $29(43 \%)$ & $39(57 \%)$ & 0.19 \\
\hline \multicolumn{5}{|l|}{ Stage } \\
\hline I & $115(55 \%)$ & $63(55 \%)$ & $52(45 \%)$ & \\
\hline II-III & $96(45 \%)$ & $41(43 \%)$ & $55(57 \%)$ & 0.10 \\
\hline \multicolumn{5}{|l|}{ EGFR } \\
\hline Wild-type & $184(87 \%)$ & $87(47 \%)$ & $97(53 \%)$ & \\
\hline Mutant & $27(13 \%)$ & $17(63 \%)$ & $10(37 \%)$ & 0.15 \\
\hline
\end{tabular}

NSCLC: Non-small cell lung carcinoma; T factor: tumor factor; $\mathrm{N}$ factor: node factor; EGFR: epidermal growth factor receptor.

and PD-L1 expression (HR 1.80, $p<0.01)$ were significant predictors of survival in univariate analysis (Table II). Multivariate analysis, adjusted for age, gender, pathology, p-stage, and PD-L1 expression, showed that gender (HR 2.10, $p=0.01)$ and p-stage (HR 2.40, $p<0.01)$ were statistically significant predictors of survival (Table II). In SQ patients, univariate analysis showed that p-stage (HR $2.63, p<0.01)$ and PD-L1 expression (HR 2.38, $p=0.02$ ) were significantly associated with death. In multivariate analysis, p-stage (HR 2.53, $p<0.01)$ and PD-L1 expression (HR 2.26, $p=0.02$ ) were found to be independent predictors of death in SQ patients (Table II). In stage I patients, univariate analysis showed that age (HR 2.52, $p=0.03$ ), gender (HR 3.59, $p<0.01$ ), and PD-L1 expression (HR 2.19, $p=0.02$ ) were significantly associated with death. Gender (HR 3.57, $p<0.01$ ) and PD-L1 expression (HR 2.05, $p=0.04$ ) were found to be independent predictors of death in multivariate analysis (Table II). Thus, PD-L1 expression was significantly correlated with death for squamous cell carcinoma patients with stages IIII and NSCLC patients with stage I disease.
PD-L1 expression in EGFR-mutant NSCLC patients. We also examined PD-L1 expression by IHC using tumor specimens from $32 E G F R$-mutant NSCLC patients treated with first generation EGFR-TKIs such as gefitinib and erlotinib. The 32 specimens included those from 17 surgical resections as well as 15 patients with transbronchial lung biopsies, in addition to a computer tomography-guided needle lung biopsy. Twenty-one cases $(66 \%)$ stained positive for PD-L1 (PD-L1+), and 11 cases (34\%) stained negative for PD-L1 (PD-L1-). The association between patient clinicopathologic parameters and PD-L1 status are shown in Table III. There were no significant associations between the expression of PD-L1 and parameters such as age, gender, and smoking status. Furthermore, there was no significant association between PD-L1 expression and the response to EGFR-TKI therapy. We next evaluated correlations between PD-L1 expression and the prognoses of EGFR mutation positive NSCLC patients. PFS was not significantly different between PD-L1+ and PD-L1- EGFR-mutant NSCLC patients $(p=0.58$; Figure $3 \mathrm{~A})$. In addition, we did not find a significant difference in overall survival between PD-L1+ and PD-1- EGFR-mutant NSCLC patients ( $p=0.20$; Figure 3B). 
Table II. Univariate and multivariate Cox proportional hazard models of factors associated with deaths in NSCLC cases.

\begin{tabular}{|c|c|c|c|c|c|c|c|}
\hline \multirow[b]{2}{*}{ Characteristics } & \multirow{2}{*}{$\begin{array}{l}\text { Comparison } \\
\text { reference } v s \text {. risk group }\end{array}$} & \multicolumn{3}{|c|}{ Univariate analysis } & \multicolumn{3}{|c|}{ Multivariate analysis } \\
\hline & & HR & $95 \% \mathrm{CI}$ & $p$-Value & HR & $95 \% \mathrm{CI}$ & $p$-Value \\
\hline \multicolumn{8}{|c|}{ Non-small cell carcinoma $(n=211)$} \\
\hline Age & $<65 v s . \geq 65$ & 1.85 & $1.10,3.09$ & 0.02 & 1.52 & $0.90,2.58$ & 0.12 \\
\hline Gender & Female $v s$. male & 2.49 & $1.44,4.29$ & $<0.01$ & 2.09 & $1.16,3.77$ & 0.01 \\
\hline Smoking & Never $v s$. current/former & 1.25 & $0.74,2.11$ & 0.40 & & & \\
\hline Pathology & Adenocarcinoma $v s$. squamous & 1.83 & $1.19,2.82$ & $<0.01$ & 1.21 & $0.52,1.32$ & 0.42 \\
\hline Grade & $\mathrm{G} 1$ vs. G2+3 & 1.24 & $0.71,2.14$ & 0.45 & & & \\
\hline p-Stage & I $v s$. II-III & 2.55 & $1.64,3.96$ & $<0.01$ & 2.38 & $1.52,3.72$ & $<0.01$ \\
\hline EGFR & Mutant $v s$. wild-type & 1.53 & $0.76,3.05$ & 0.23 & & & \\
\hline PD-L1 expression & Negative $v s$. positive & 1.80 & $1.16,2.79$ & $<0.01$ & 1.37 & $0.92,2.25$ & 0.11 \\
\hline \multicolumn{8}{|c|}{ Squamous cell carcinoma $(n=86)$} \\
\hline Age & $<65$ vs. $\geq 65$ & 1.65 & $0.69,3.96$ & 0.23 & & & \\
\hline Gender & Female $v s$. male & 1.33 & $0.41,4.31$ & 0.64 & & & \\
\hline Smoking & Never $v s$. current/former & 0.77 & $0.27,2.16$ & 0.62 & & & \\
\hline Grade & $\mathrm{G} 1$ vs. G2+3 & 0.64 & $0.28,1.45$ & 0.28 & & & \\
\hline p-Stage & I $v s$. II-III & 2.63 & $1.36,5.07$ & $<0.01$ & 2.53 & $1.30,4.91$ & $<0.01$ \\
\hline PD-L1 expression & Negative $v s$. positive & 2.38 & $1.19,2.38$ & 0.02 & 2.26 & $1.13,4.55$ & 0.02 \\
\hline \multicolumn{8}{|l|}{ Stage I $(n=114)$} \\
\hline Age & $<65$ vs. $\geq 65$ & 2.52 & $1.10,5.80$ & 0.03 & 2.27 & $0.98,5.25$ & 0.06 \\
\hline Gender & Female $v s$. male & 3.59 & $1.39,9.25$ & $<0.01$ & 3.57 & $1.39,9.21$ & $<0.01$ \\
\hline Smoking & Never vs. current/former & 1.49 & $0.62,3.59$ & 0.38 & & & \\
\hline Pathology & Squamous vs. adenocarcinoma & 1.57 & $0.80,3.07$ & 0.19 & & & \\
\hline Grade & $\mathrm{G} 1$ vs. $\mathrm{G} 2+3$ & 1.57 & $0.68,3.63$ & 0.30 & & & \\
\hline EGFR & Mutant $v s$. wild-type & 1.26 & $0.49,3.24$ & 0.64 & & & \\
\hline PD-L1 expression & Negative $v s$. positive & 2.19 & $1.11,4.30$ & 0.02 & 2.05 & $0.92,4.05$ & 0.04 \\
\hline
\end{tabular}

NSCLC: Non-small cell lung carcinoma; p-stage: pathological findings stage; EGFR: epidermal growth factor receptor.

\section{Discussion}

In this study, PD-L1-positive expression in tumor tissue was a significant independent predictor of a poor outcome in patients with lung SQ and in stage I NSCLC patients. In contrast, we did not find a significant correlation between PD-L1 expression and survival in EGFR-mutant NSCLC patients. Additionally, a significant correlation between PDL1 expression and response to EGFR-TKIs was also not found in NSCLC patients with an EGFR mutation.

Previous studies have yielded controversial results concerning the association between PD-LI expression and clinical outcome using various PD-L1 antibody clones, IHC scoring systems and cut off values $(13,15-18,28-31)$. Several studies have shown that a tumor with a high level of PD-L1 expression, based on the median value of all $\mathrm{H}$ scores, was associated with significantly shorter overall survival in NSCLC patients $(13,16)$. In contrast, PD-L1 expression has been associated with a significantly better survival outcome in NSCLC patients $(15,18)$. The conflicting results of previous reports may reflect differences in patient background, such as race, or differences in PD-L1
Table III. Association between PD-L1 expression and patient characteristics of EGFR-mutant NSCLC patients.

\begin{tabular}{lcccc}
\hline Variables & $\mathrm{N}$ & $\mathrm{PD}-\mathrm{L} 1+$ & $\mathrm{PD}-\mathrm{L} 1-$ & $p$-Value \\
\hline $\begin{array}{l}\text { Total, n=32 } \\
\text { Age (years) }\end{array} \quad$ & & $21(66 \%)$ & $11(34 \%)$ & \\
$\quad<65$ & $13(41 \%)$ & $9(69 \%)$ & $4(31 \%)$ & \\
$\quad \geq 65$ & $19(59 \%)$ & $12(63 \%)$ & $7(37 \%)$ & 0.51 \\
Gender & & & & \\
$\quad$ Male & $12(38 \%)$ & $6(50 \%)$ & $6(50 \%)$ & \\
$\quad$ Female & $20(62 \%)$ & $15(75 \%)$ & $5(25 \%)$ & 0.15 \\
Smoking & & & & \\
$\quad$ Never smoked & $27(84 \%)$ & $18(67 \%)$ & $9(33 \%)$ & \\
$\quad$ Current/former smoker & $5(16 \%)$ & $3(60 \%)$ & $2(40 \%)$ & 0.57 \\
EGFR mutation & & & & \\
$\quad$ Exon 19 & $20(63 \%)$ & $15(75 \%)$ & $5(25 \%)$ & \\
$\quad$ Exon 21 & $12(37 \%)$ & $6(50 \%)$ & $6(50 \%)$ & 0.25 \\
EGFR-TKI response & $23(72 \%)$ & $15(65 \%)$ & $8(35 \%)$ & \\
$\quad$ CR/PR & $9(28 \%)$ & $6(67 \%)$ & $3(37 \%)$ & 0.64 \\
$\quad$ SD/PD & & & & \\
\hline
\end{tabular}

NSCLC: Non-small cell lung carcinoma; EGFR: epidermal growth factor receptor; EGFR-TKI: epidermal growth factor receptor-tyrosine kinase inhibitor; CR: complete response; PR: partial response; SD: stable disease; PD: progressive disease. 
A

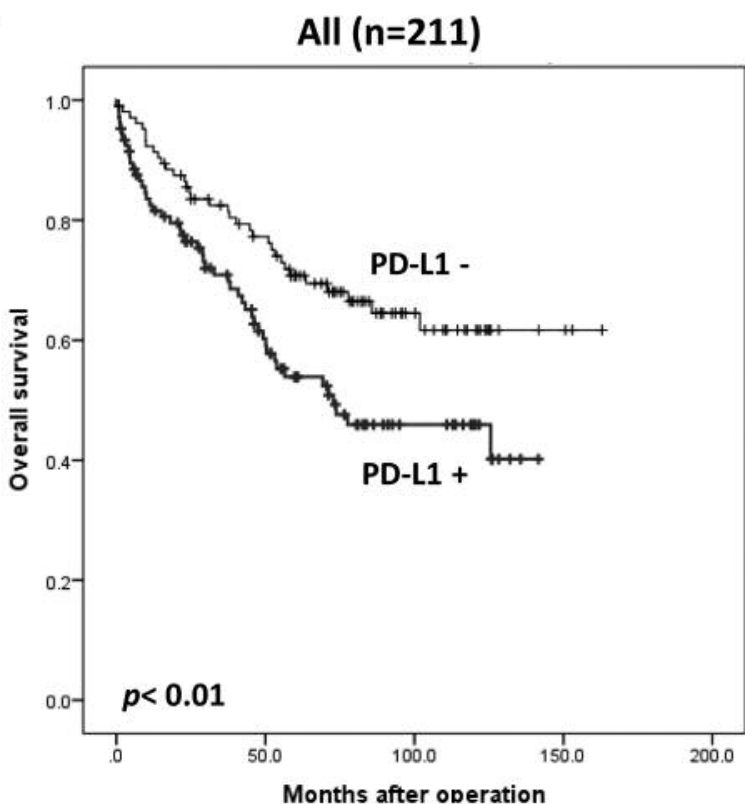

$\mathbf{C}$

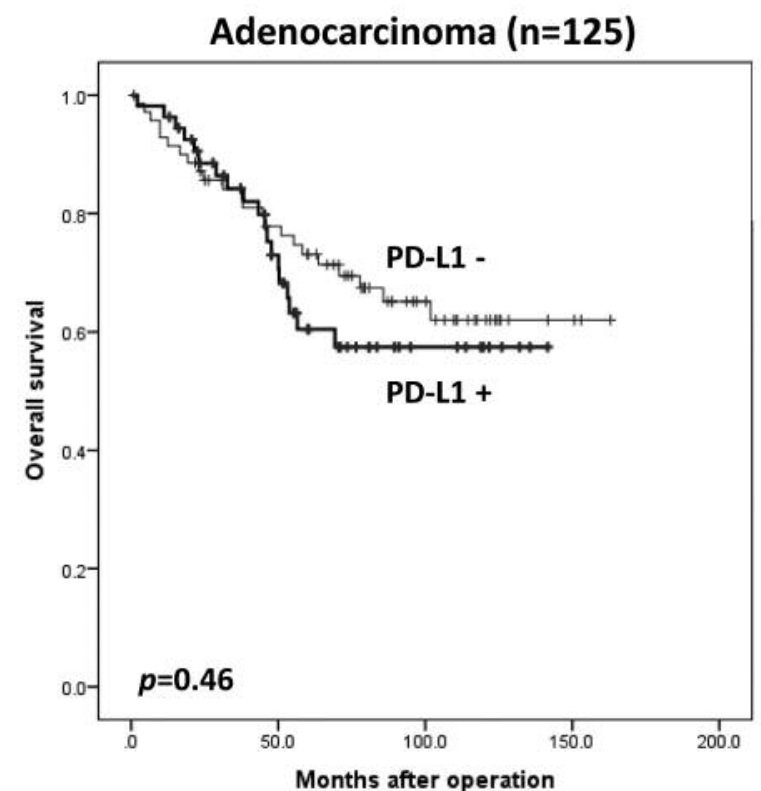

B

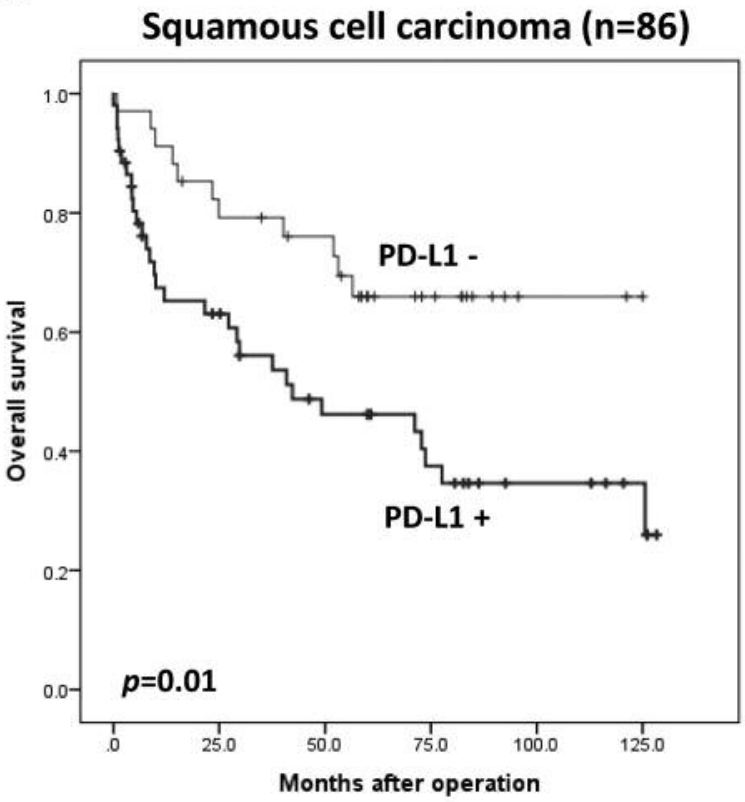

D

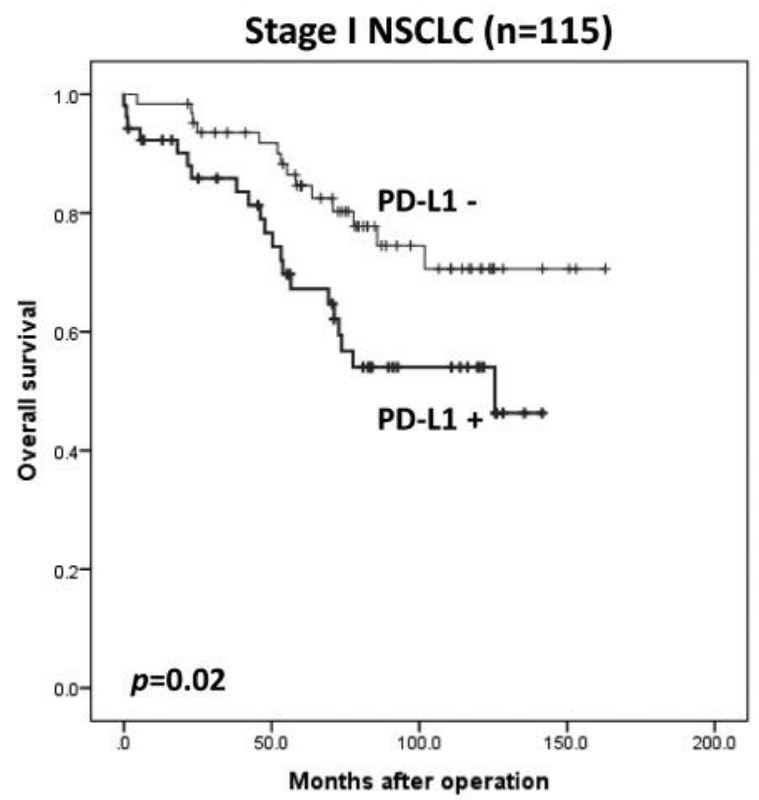

Figure 2. Kaplan-Meier analyses of overall survival in NSCLC patients. A) A significant difference in overall survival was found between PD-L1 positive and negative groups in 211 NSCLC patients $(p<0.01)$. (B) A significant difference in overall survival was found between PD-L1 positive and negative groups in $86 S Q$ patients $(p=0.01)$. (C) No significant difference in overall survival was found between PD-L1 positive and PD-L1 negative groups in 125 adenocarcinoma patients. (D) A significant difference in overall survival was found between PD-L1 positive and negative groups in 114 NSCLC patients with stage I disease ( $p=0.02)$. The significance of the difference in overall survival between subgroups was analyzed by a long-rank test.

antibody clones, IHC scoring systems and cutoff values. Meta-analysis revealed that high PD-L1 expression was a poor prognostic factor in Chinese, but this finding did not apply to non-Chinese or NSCLC patients (32). The Blueprint
PD-L1 IHC Assay Comparison Project using four PD-L1 IHC assays, and anti-PD-L1 (22C3, 28-8, SP142, and SP263) antibody clones as used in clinical trials revealed that three of the four assays (excluding SP142) were closely 
A

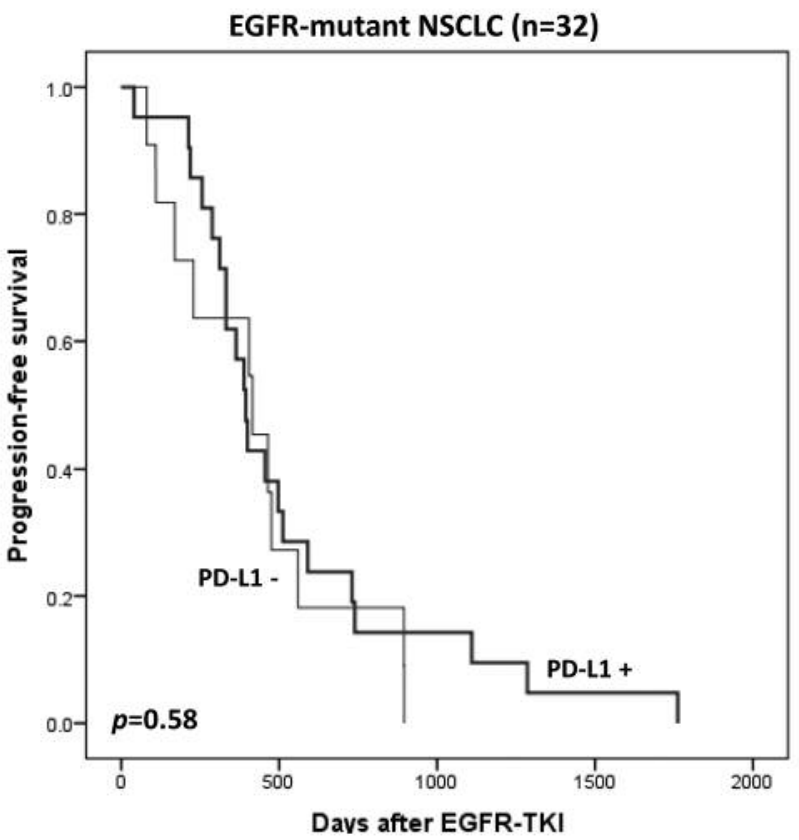

B

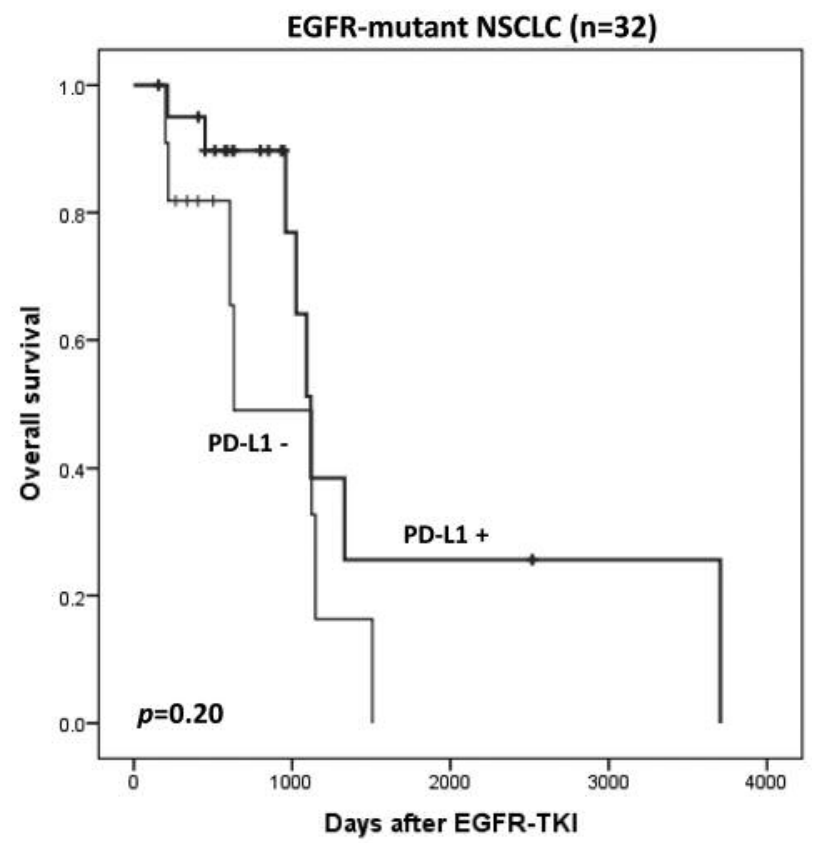

Figure 3. Kaplan-Meier analyses of progression-free survival and overall survival in EGFR-mutant NSCLC patients after EGFR-TKI therapy. (A) Progression-free curves of 32 EGFR-mutant NSCLC patients with PD-L1 positive or negative expression after EGFR-TKI therapy. (B) Overall survival curves of 32 EGFR-mutant NSCLC patients with PD-L1 positive or negative expression. The significance of the difference in overall survival between subgroups was analyzed by the long-rank test.

aligned in tumor cell staining (33). However, a different PDL1 classification (37\%), depending on the assay/scoring system used, was found (33). Variability in PD-L1 staining patterns in immune cells between cases was also observed. The current study was performed using a non-standard PDL1 assay that has not been compared with any of the four clinical available assays. The polyclonal antibody of this assay was used in a previous study to evaluate the prognosis of NSCLC patients (16). However, a comparison between the current antibody and the four antibodies used in clinical trials, to date, has not been reported. This is one of the limitations of this study. Furthermore, the presence of heterogeneity within tumors should be considered when objectively determining PD-L1 protein expression levels in NSCLC patients (34).

This is the first report showing that PD-L1 positive expression in tumors was a significant independent predictor of a poor outcome in lung SQ lung patients. Recently, the tumor mutation burden (TMB) has been recognized as one of the predictive factors of immunogenicity. Rizvi et al. demonstrated that the genomic landscape of lung cancers shapes the response to anti-PD-1 therapy (35). Because many carcinogens are induced by tobacco smoke, smoking-related malignancies, including lung SQ, have a high genome-wide burden of mutation (36). Therefore, PD-L1 expression may be involved in patient survival as well as the response to anti-PD-1/PD-L1 inhibitors in lung SQ patients. Besides PDL1 and TMB, the PD-L1 levels of tumor-infiltrating lymphocytes and myeloid cells were also important factors in the response to PD-1 immune checkpoint inhibitor (37, 38). Thus, the association between the tumor and tumor microenvironment needs to be evaluated to clarify the significance of patient survival in lung cancer.

Several studies have demonstrated that PD-L1 was strongly associated with the presence of EGFR mutations, potentially modulating their sensitivity to anti-EGFR agent $(15,16,23)$. Akbay et al. showed that activation of the EGFR pathway induces PD-L1 expression to facilitate evasion of the host's anti-tumor immune suppression (23). Azuma et al. revealed that the PD-L1 expression level at the cell surface was significantly higher for NSCLC cells with $E G F R$ mutations than for those with wild-type EGFR, and that erlotinib could downregulate PD-L1 expression (16). However, we did not find significant PD-L1 expression that was associated with overall survival or the response to EGFR-TKI in EGFR-mutant NSCLC patients. Nivolumab led to significantly improved overall survival compared with docetaxel in previously treated non-SQ NSCLC patients, but 
not in an EGFR-mutant subgroup (6). Thus, the clinical significance of PD-L1 expression in NSCLC patients with $E G F R$ mutations is still unknown.

In EGFR-mutant NSCLC patients, tumor samples from surgical resections and transbronchial lung biopsies were used in this study. Immunohistochemical staining of transbronchial lung biopsies may sometimes yield false positive and negative results. For example, a recent report showed that PD-L1 expression was frequently discordant between surgically resected and matched biopsy specimens (the overall discordance rate being 48\%) (39). This may explain why we found the evaluation of PD-L1 expression in diagnostic biopsies to be misleading when defining patient's sensitivity to treatment with PD-L1 targeted therapy.

In conclusion, PD-L1-positive expression in a tumor was a significant independent predictor of a poor outcome in patients with lung SQ carcinoma and stage I NSCLC patients. In contrast, a PD-L1 expression status was not associated with the response to EGFR-TKI and a prognosis in NSCLC patients with an EGFR mutation. A PD-L1 expression status may be useful for the identification of SQ carcinoma and stage I NSCLC patients at high risk of postoperative death and who would benefit from adjuvant chemotherapy using anti-PD1 and anti-PD-L1 antibodies.

\section{Conflicts of Interest}

The Authors have stated that they have no conflicts of interest.

\section{Acknowledgements}

This study was supported in part by a grant-in-aid from the Ministry of Education, Culture, Sports, Science, and Technology of Japan (grant no. 25461172 to A. Gemma), and the Clinical Rebiopsy Bank Project for Comprehensive Cancer Therapy Development at Nippon Medical School.

\section{References}

1 Siegel RL, Miller KD and Jemal A: Cancer Statistics, 2017. CA Cancer J Clin 67: 7-30, 2017.

2 Shaw AT, Kim DW, Nakagawa K, Seto T, Crino L, Ahn MJ, De Pas T, Besse B, Solomon BJ, Blackhall F, Wu YL, Thomas M, O'Byrne KJ, Moro-Sibilot D, Camidge DR, Mok T, Hirsh V, Riely GJ, Iyer S, Tassell V, Polli A, Wilner KD and Janne PA: Crizotinib versus chemotherapy in advanced ALK-positive lung cancer. N Engl J Med 368: 2385-2394, 2013.

3 Maemondo M, Inoue A, Kobayashi K, Sugawara S, Oizumi S, Isobe H, Gemma A, Harada M, Yoshizawa H, Kinoshita I, Fujita Y, Okinaga S, Hirano H, Yoshimori K, Harada T, Ogura T, Ando M, Miyazawa H, Tanaka T, Saijo Y, Hagiwara K, Morita S and Nukiwa T: Gefitinib or chemotherapy for non-small-cell lung cancer with mutated EGFR. N Engl J Med 362: 2380-2388, 2010.

4 Mitsudomi T, Morita S, Yatabe Y, Negoro S, Okamoto I, Tsurutani J, Seto T, Satouchi M, Tada H, Hirashima T, Asami K, Katakami N, Takada M, Yoshioka H, Shibata K, Kudoh S, Shimizu E, Saito H, Toyooka S, Nakagawa K and Fukuoka M:
Gefitinib versus cisplatin plus docetaxel in patients with nonsmall-cell lung cancer harbouring mutations of the epidermal growth factor receptor (WJTOG3405): an open label, randomised phase 3 trial. Lancet Oncol 11: 121-128, 2010.

5 Brahmer J, Reckamp KL, Baas P, Crino L, Eberhardt WE, Poddubskaya E, Antonia S, Pluzanski A, Vokes EE, Holgado E, Waterhouse D, Ready N, Gainor J, Aren Frontera O, Havel L, Steins M, Garassino MC, Aerts JG, Domine M, Paz-Ares L, Reck M, Baudelet C, Harbison CT, Lestini B and Spigel DR: Nivolumab versus Docetaxel in Advanced Squamous-Cell NonSmall-Cell Lung Cancer. N Engl J Med 373: 123-135, 2015.

6 Borghaei H, Paz-Ares L, Horn L, Spigel DR, Steins M, Ready NE, Chow LQ, Vokes EE, Felip E, Holgado E, Barlesi F, Kohlhaufl M, Arrieta O, Burgio MA, Fayette J, Lena H, Poddubskaya E, Gerber DE, Gettinger SN, Rudin CM, Rizvi N, Crino L, Blumenschein GR Jr., Antonia SJ, Dorange C, Harbison $\mathrm{CT}$, Graf Finckenstein $\mathrm{F}$ and Brahmer JR: Nivolumab versus Docetaxel in Advanced Nonsquamous Non-Small-Cell Lung Cancer. N Engl J Med 373: 1627-1639, 2015.

7 Herbst RS, Baas P, Kim DW, Felip E, Perez-Gracia JL, Han JY, Molina J, Kim JH, Arvis CD, Ahn MJ, Majem M, Fidler MJ, de Castro G Jr., Garrido M, Lubiniecki GM, Shentu Y, Im E, DolledFilhart $\mathrm{M}$ and Garon EB: Pembrolizumab versus docetaxel for previously treated, PD-L1-positive, advanced non-small-cell lung cancer (KEYNOTE-010): a randomised controlled trial. Lancet (London, England) 387: 1540-1550, 2016.

8 Rittmeyer A, Barlesi F, Waterkamp D, Park K, Ciardiello F, von Pawel J, Gadgeel SM, Hida T, Kowalski DM, Dols MC, Cortinovis DL, Leach J, Polikoff J, Barrios C, Kabbinavar F, Frontera OA, De Marinis F, Turna H, Lee JS, Ballinger M, Kowanetz M, He P, Chen DS, Sandler A and Gandara DR: Atezolizumab versus docetaxel in patients with previously treated non-small-cell lung cancer (OAK): a phase 3, open-label, multicentre randomised controlled trial. Lancet (London, England) 389: 255-265, 2017.

9 Antonia S, Brahmer JR, Khleif S, Balmanoukian AS, Ou S-HI, Gutierrez M, Kim D-W, Kim S-W, Ahn MJ, Leach J, Jamal R, Jaeger D, Jerusalem G, Jin X, Gupta A, Antal J and Segal NH: Phase $1 / 2$ study of the safety and clinical activity of durvalumab in patients with non-small cell lung cancer (NSCLC). Ann Oncol 27: vi416-vi454, 2016.

10 Reck M, Rodriguez-Abreu D, Robinson AG, Hui R, Csoszi T, Fulop A, Gottfried M, Peled N, Tafreshi A, Cuffe S, O'Brien M, Rao S, Hotta K, Leiby MA, Lubiniecki GM, Shentu Y, Rangwala $\mathrm{R}$ and Brahmer JR: Pembrolizumab versus Chemotherapy for PD-L1-Positive Non-Small-Cell Lung Cancer. NEngl J Med 375: 1823-1833, 2016.

11 Socinski M, Creelan B, Horn L, Reck M, Paz-Ares L, Steins M, Felip E, Van den Heuvel M, Ciuleanu TE, Badin F, Ready N, Hiltermann TN, Nair S, Juergens R, Peters S, Minenza E, Geese WJ, Bhagavatheeswaran B, Chen A and Carbone DP: CheckMate 026: A phase 3 trial of nivolumab vs investigator's choice (IC) of platinum-based doublet chemoterapy (PT-DC) as first-line therapy for stage iv/recurrent programmed death ligand 1 (PD-L1)-positive NSCLC. Annals Oncol 27: 552-587, 2016.

12 Yang CY, Lin MW, Chang YL, Wu CT and Yang PC: Programmed cell death-ligand 1 expression in surgically resected stage I pulmonary adenocarcinoma and its correlation with driver mutations and clinical outcomes. Eur J Cancer 50: 13611369,2014 
$13 \mathrm{Mu}$ CY, Huang JA, Chen Y, Chen $\mathrm{C}$ and Zhang XG: High expression of PD-L1 in lung cancer may contribute to poor prognosis and tumor cells immune escape through suppressing tumor infiltrating dendritic cells maturation. Med Oncol (Northwood, London, England) 28: 682-688, 2011.

14 Zhang Y, Wang L, Li Y, Pan Y, Wang R, Hu H, Li H, Luo X, Ye $\mathrm{T}$, Sun $\mathrm{Y}$ and Chen H: Protein expression of programmed death 1 ligand 1 and ligand 2 independently predict poor prognosis in surgically resected lung adenocarcinoma. OncoTargets Ther 7: 567-573, 2014.

15 D'Incecco A, Andreozzi M, Ludovini V, Rossi E, Capodanno A, Landi L, Tibaldi C, Minuti G, Salvini J, Coppi E, Chella A, Fontanini G, Filice ME, Tornillo L, Incensati RM, Sani S, Crino L, Terracciano L and Cappuzzo F: PD-1 and PD-L1 expression in molecularly selected non-small-cell lung cancer patients. $\mathrm{Br}$ J Cancer 112: 95-102, 2015.

16 Azuma K, Ota K, Kawahara A, Hattori S, Iwama E, Harada T, Matsumoto K, Takayama K, Takamori S, Kage M, Hoshino T, Nakanishi Y and Okamoto I: Association of PD-L1 overexpression with activating EGFR mutations in surgically resected nonsmallcell lung cancer. Ann Oncol 25: 1935-1940, 2014.

17 Velcheti V, Schalper KA, Carvajal DE, Anagnostou VK, Syrigos KN, Sznol M, Herbst RS, Gettinger SN, Chen L and Rimm DL: Programmed death ligand-1 expression in non-small cell lung cancer. LabI Invest 94: 107-116, 2014.

18 Cooper WA, Tran T, Vilain RE, Madore J, Selinger CI, Kohonen-Corish M, Yip P, Yu B, O'Toole SA, McCaughan BC, Yearley JH, Horvath LG, Kao S, Boyer M and Scolyer RA: PD-L1 expression is a favorable prognostic factor in early stage non-small cell carcinoma. Lung Cancer 89: 181-188, 2015.

19 Asamura H, Goya T, Koshiishi Y, Sohara Y, Eguchi K, Mori M, Nakanishi Y, Tsuchiya R, Shimokata K, Inoue H, Nukiwa T and Miyaoka E: A Japanese Lung Cancer Registry study: prognosis of 13,010 resected lung cancers. J Thorac Oncol 3: 46-52, 2008.

20 Arriagada R, Bergman B, Dunant A, Le Chevalier T, Pignon JP and Vansteenkiste $\mathrm{J}$ : Cisplatin-based adjuvant chemotherapy in patients with completely resected non-small-cell lung cancer. N Engl J Med 350: 351-360, 2004.

21 Winton T, Livingston R, Johnson D, Rigas J, Johnston M, Butts C, Cormier Y, Goss G, Inculet R, Vallieres E, Fry W, Bethune D, Ayoub J, Ding K, Seymour L, Graham B, Tsao MS, Gandara D, Kesler K, Demmy $\mathrm{T}$ and Shepherd F: Vinorelbine plus cisplatin $v s$. observation in resected non-small-cell lung cancer. N Engl J Med 352: 2589-2597, 2005.

22 Douillard JY, Rosell R, De Lena M, Carpagnano F, Ramlau R, Gonzales-Larriba JL, Grodzki T, Pereira JR, Le Groumellec A, Lorusso V, Clary C, Torres AJ, Dahabreh J, Souquet PJ, Astudillo J, Fournel P, Artal-Cortes A, Jassem J, Koubkova L, His P, Riggi $\mathrm{M}$ and Hurteloup P: Adjuvant vinorelbine plus cisplatin versus observation in patients with completely resected stage IB-IIIA non-small-cell lung cancer (Adjuvant Navelbine International Trialist Association [ANITA]): a randomised controlled trial. Lancet Oncol 7: 719-727, 2006.

23 Akbay EA, Koyama S, Carretero J, Altabef A, Tchaicha JH, Christensen CL, Mikse OR, Cherniack AD, Beauchamp EM, Pugh TJ, Wilkerson MD, Fecci PE, Butaney M, Reibel JB, Soucheray M, Cohoon TJ, Janne PA, Meyerson M, Hayes DN, Shapiro GI, Shimamura T, Sholl LM, Rodig SJ, Freeman GJ,
Hammerman PS, Dranoff G and Wong KK: Activation of the PD-1 pathway contributes to immune escape in EGFR-driven lung tumors. Cancer Discov 3: 1355-1363, 2013.

24 Lee CK, Man J, Lord S, Links M, Gebski V, Mok T and Yang JC: Checkpoint Inhibitors in Metastatic EGFR-Mutated NonSmall Cell Lung Cancer-A Meta-Analysis. J Thorac Oncol 12: 403-407, 2017.

25 Goldstraw P, Chansky K, Crowley J, Rami-Porta R, Asamura H, Eberhardt WE, Nicholson AG, Groome P, Mitchell A and Bolejack V: The IASLC Lung Cancer Staging Project: Proposals for Revision of the TNM Stage Groupings in the Forthcoming (Eighth) Edition of the TNM Classification for Lung Cancer. J Thorac Oncol 11: 39-51, 2016.

26 Travis WD, Brambilla E, Noguchi M, Nicholson AG, Geisinger KR, Yatabe Y, Beer DG, Powell CA, Riely GJ, Van Schil PE, Garg K, Austin JH, Asamura H, Rusch VW, Hirsch FR, Scagliotti G, Mitsudomi T, Huber RM, Ishikawa Y, Jett J, Sanchez-Cespedes M, Sculier JP, Takahashi T, Tsuboi M, Vansteenkiste J, Wistuba I, Yang PC, Aberle D, Brambilla C, Flieder D, Franklin W, Gazdar A, Gould M, Hasleton P, Henderson D, Johnson B, Johnson D, Kerr K, Kuriyama K, Lee JS, Miller VA, Petersen I, Roggli V, Rosell R, Saijo N, Thunnissen E, Tsao M and Yankelewitz D: International association for the study of lung cancer/american thoracic society/european respiratory society international multidisciplinary classification of lung adenocarcinoma. J Thorac Oncol 6: 244-285, 2011.

27 Edge SB and Compton CC: The American Joint Committee on Cancer: the 7th edition of the AJCC cancer staging manual and the future of TNM. Annals of surgical oncology 17: 1471-1474, 2010.

28 Konishi J, Yamazaki K, Azuma M, Kinoshita I, Dosaka-Akita H and Nishimura M: B7-H1 expression on non-small cell lung cancer cells and its relationship with tumor-infiltrating lymphocytes and their PD-1 expression. Clin Cancer Res 10: 5094-5100, 2004.

29 Tang Y, Fang W, Zhang Y, Hong S, Kang S, Yan Y, Chen N, Zhan J, He X, Qin T, Li G, Tang W, Peng P and Zhang L: The association between PD-L1 and EGFR status and the prognostic value of PD-L1 in advanced non-small cell lung cancer patients treated with EGFR-TKIs. Oncotarget 6: 14209-14219, 2015.

30 Chen YB, Mu CY and Huang JA: Clinical significance of programmed death-1 ligand-1 expression in patients with nonsmall cell lung cancer: a 5-year-follow-up study. Tumori 98: 751-755, 2012.

31 Mao Y, Li W, Chen K, Xie Y, Liu Q, Yao M, Duan W, Zhou X, Liang $\mathrm{R}$ and Tao $\mathrm{M}$ : B7-H1 and B7-H3 are independent predictors of poor prognosis in patients with non-small cell lung cancer. Oncotarget 6: 3452-3461, 2015.

32 Zhong A, Xing Y, Pan X, Shi M and Xu H: Prognostic value of programmed cell death-ligand 1 expression in patients with nonsmall-cell lung cancer: evidence from an updated meta-analysis. OncoTargets Ther 8: 3595-3601, 2015.

33 Hirsch FR, McElhinny A, Stanforth D, Ranger-Moore J, Jansson M, Kulangara K, Richardson W, Towne P, Hanks D, Vennapusa B, Mistry A, Kalamegham R, Averbuch S, Novotny J, Rubin E, Emancipator K, McCaffery I, Williams JA, Walker J, Longshore J, Tsao MS and Kerr KM: PD-L1 Immunohistochemistry Assays for Lung Cancer: Results from Phase 1 of the Blueprint PD-L1 IHC Assay Comparison Project. J Thorac Oncol 12: 208-222, 2017. 
34 McLaughlin J, Han G, Schalper KA, Carvajal-Hausdorf D, Pelekanou V, Rehman J, Velcheti V, Herbst R, LoRusso P and Rimm DL: Quantitative Assessment of the Heterogeneity of PDL1 Expression in Non-Small-Cell Lung Cancer. JAMA oncology 2: 46-54, 2016.

35 Rizvi NA, Hellmann MD, Snyder A, Kvistborg P, Makarov V, Havel JJ, Lee W, Yuan J, Wong P, Ho TS, Miller ML, Rekhtman N, Moreira AL, Ibrahim F, Bruggeman C, Gasmi B, Zappasodi R, Maeda Y, Sander C, Garon EB, Merghoub T, Wolchok JD, Schumacher TN and Chan TA: Cancer immunology. Mutational landscape determines sensitivity to PD-1 blockade in non-small cell lung cancer. Science (New York, NY) 348: 124-128, 2015.

36 Gibbons DL, Byers LA and Kurie JM: Smoking, p53 mutation, and lung cancer. Molecular cancer research: MCR 12: 3-13, 2014.

37 Juneja VR, McGuire KA, Manguso RT, LaFleur MW, Collins N, Haining WN, Freeman GJ and Sharpe AH: PD-L1 on tumor cells is sufficient for immune evasion in immunogenic tumors and inhibits CD8 T cell cytotoxicity. J Exper Med 214: 895-904, 2017.
38 Prat A, Navarro A, Pare L, Reguart N, Galvan P, Pascual T, Martinez A, Nuciforo P, Comerma L, Alos L, Pardo N, Cedres S, Fan C, Parker JS, Gaba L, Victoria I, Vinolas N, Vivancos A, Arance A and Felip E: Immune-Related Gene Expression Profiling After PD-1 Blockade in Non-Small Cell Lung Carcinoma, Head and Neck Squamous Cell Carcinoma, and Melanoma. Cancer Res 77: 3540-3550, 2017.

39 Ilie M, Long-Mira E, Bence C, Butori C, Lassalle S, Bouhlel L, Fazzalari L, Zahaf K, Lalvee S, Washetine K, Mouroux J, Venissac N, Poudenx M, Otto J, Sabourin JC, Marquette CH, Hofman V and Hofman P: Comparative study of the PD-L1 status between surgically resected specimens and matched biopsies of NSCLC patients reveal major discordances: a potential issue for anti-PD-L1 therapeutic strategies. Ann Oncol 27: 147-153, 2016.

Received November 20, 2017

Revised December 6, 2017

Accepted December 7, 2017 